\title{
Alterations in the Th1/Th2 balance in breast cancer patients using reflexology and scalp massage
}

\author{
VICTORIA L. GREEN ${ }^{1}$, AFRODITI ALEXANDROPOULOU ${ }^{1}$, MARY B. WALKER ${ }^{2}$, \\ ANDREW A. WALKER ${ }^{2}$, DONALD M. SHARP ${ }^{2}$, LESLIE G. WALKER ${ }^{2}$ and JOHN GREENMAN ${ }^{1}$ \\ ${ }^{1}$ Postgraduate Medical Institute, University of Hull in association with Hull-York Medical School; \\ ${ }^{2}$ Postgraduate Medical Institute, Oncology Health Centres, University of Hull and Hull and East Yorkshire Hospitals \\ NHS Trust, in association with Hull-York Medical School, Kingston upon Hull, UK
}

Received September 7, 2009; Accepted October 20, 2009

DOI: 10.3892/etm_00000018

\begin{abstract}
The diagnosis and treatment of breast cancer can adversely affect quality of life. Here the aim was to determine the effects of reflexology on host defences and endocrine function in women with early breast cancer. Six weeks after surgery for early breast cancer, 183 women were randomly assigned to self-initiated support (SIS), SIS plus foot reflexology, or SIS plus scalp massage. Peripheral blood mononuclear cells and serum were isolated at T1 (6 weeks post surgery; baseline), $\mathrm{T} 2$ and T3 (4 and 10 weeks post completion of intervention, respectively). Lymphocyte phenotyping found that $\mathrm{CD} 25^{+}$ cells were significantly higher in the massage group compared with the SIS group at T3. The percentage of T cells, and more specifically the $\mathrm{T}$ helper subset expressing IL4, decreased significantly in the massage group compared with the SIS group at T3. This change was accompanied by an increase in the percentage of $\mathrm{CD}^{+} \mathrm{T}$ cytotoxic cells expressing IFN $\gamma$ in the massage group. Natural killer and lymphokine activated killer cell cytotoxicity measurements, serum levels of cortisol, prolactin and growth hormone, and flow cytometric assessment of their corresponding receptors all revealed no significant differences between the three groups of patients. This study provides evidence that the immunological balance of patients can be altered in a potentially beneficial manner by massage. The original trial was registered with the International Standard Randomised Controlled Trial Registry (ISRCTN87652313).
\end{abstract}

\section{Introduction}

Worldwide, over one million women are diagnosed annually with breast cancer, equating to a tenth of all new cancers

Correspondence to: Dr Victoria L. Green, Centre for Biomedical Research, University of Hull, Cottingham Road, Hull, HU6 7RX, UK

E-mail: v.l.green@hull.ac.uk

Key words: breast cancer, complementary and alternative therapies, stress, immune response, neuroendocrine and $23 \%$ of female cancers. Eighty percent of cases occur in women over 50 years of age, although it is also the most commonly diagnosed cancer in women under the age of 35 (1). The diagnosis and treatment of breast cancer is commonly associated with considerable psychiatric morbidity (2). For example, Hall et al (3) reported that of 269 women with early breast cancer, $49.6 \%$ were clinically anxious and $37.2 \%$ were clinically depressed in the first 3 months following surgery, whereas Burgess et al (4) found that of 222 women with early breast cancer, $48 \%$ were clinically anxious and/or depressed in the first year.

Complementary and alternative medicines (CAM) are widely used by patients with cancer to help them cope with the stress of the diagnosis and treatment of the disease $(5,6)$; with an annual expenditure exceeding $£ 1.6$ billion in the UK (7). A recent study found that $69 \%$ of breast cancer survivors reported using some form of CAM, and of these, $73 \%$ changed or initiated use due to cancer diagnosis (8). Of the many forms of CAM available, reflexology has been reported to be the most popular amongst cancer patients in the UK (used by over $35 \%$ of those receiving CAM treatment) (9).

Stress-induced immunosuppression, including that associated with the diagnosis and treatment of cancer, is now a well established immunological phenomenon (10,11). A metaanalysis by Herbert and Cohen (12) revealed a relationship between stress and decreased functional immune measures, and a more recent meta-analysis of over 300 studies also showed that the immune outcomes were dependent on the types of stress involved, e.g., acute vs. chronic stress (13).

Various parameters of the immune system are adversely affected by stress. These include natural killer (NK) cell activity, the numbers and percentages of circulating white blood cells and immunoglobulin levels (12). NK cells, and their more active IL2-stimulated counterparts, lymphokine activated killer (LAK) cells, have anti-tumour properties, but are generally suppressed in cancer patients (14); the relationship of such effects to the development and/or progression of cancer has been widely discussed but remains unresolved (15-17).

$\mathrm{T}$ helper cells play a key role in controlling the immune response. These can be subdivided further into T-helper 1 (Th1)- and T-helper 2 (Th2)-like cells; defined by the cytokine repertoire they produce and the responses they 


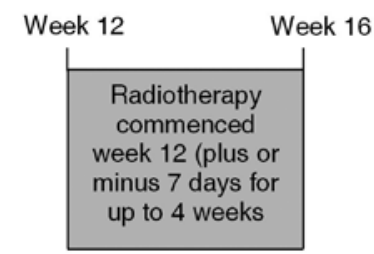

Chemotherapy Commenced week 6 (plus or minus 7 days) for up to 16 weeks

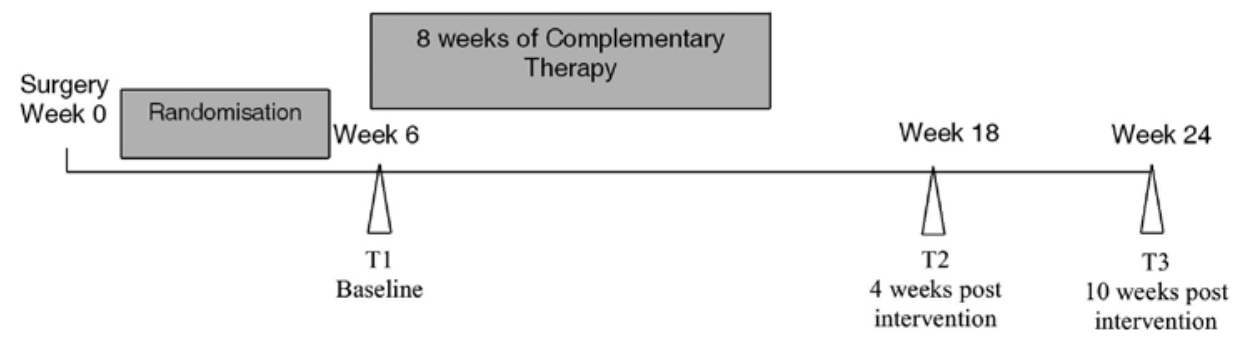

Figure 1. Timeline of complementary therapy (reflexology or scalp massage), chemotherapy and/or radiotherapy with respect to surgery and randomisation. T1 (week 6), T2 (week 18) and T3 (week 24) are the sample time points.

induce. Th1-like cells are principally involved in promoting cell-mediated immunity, initiating a cytotoxic response and generally are considered as the host's main anti-cancer mechanism (18), whereas Th2-like cells stimulate a humoral or antibody-mediated response, involved principally against extracellular pathogens. A stress response induces a shift in favour of Th2-like cells (10), which is observed in different types of cancer by changes in the concentrations of specific serum cytokines (19-21).

Stress can also alter the circulating levels of neuroendocrine hormones, in particular cortisol and to a lesser extent prolactin and growth hormone, whose effects on the immune system are widespread $(22,23)$. These are caused, at least in part, through direct activation of specific cell surface receptors expressed by immune cells (24-26). The hypothalamic-pituitary-adrenal (HPA) axis is generally regarded as the most probable pathway by which the effects of psychosocial and complementary interventions on the immune system are mediated (27-29). The stress of diagnosis and treatment of cancer is also likely to act via the HPA axis and be involved in the progression of cancer (30).

Several studies suggest that psychosocial interventions aimed at promoting coping can alter the levels of HPA hormones (31-33). In patients with cancer, psychosocial interventions can normalize (34-36), or reduce (37) cortisol levels, as well as reduce prolactin levels (36). There is potential, therefore, for stress-reducing CAM interventions to influence the immune system via this neuroendocrine pathway.

A number of previous randomised trials evaluating the effects of various behavioural, psychosocial and complementary therapies in cancer patients have demonstrated both improvements in quality of life as well as changes in biological parameters (38-43). However, diagnostic and therapeutic heterogeneity, as well as the use of different tumour types and outcome measures, limit the conclusions that can be drawn.
Previous research on breast cancer patients has shown that patients do not always comply with relaxation and guided imagery $(38,42)$; therefore, the present study was designed to evaluate an alternative well-received intervention to promote relaxation. Hence, the current randomised controlled trial evaluated the effects of reflexology and scalp massage on host defences and neuroendocrine function. Reflexology was compared with two comparator conditions, namely treatment as usual, which involves self-initiated support (SIS) in the Oncology Health Centres (44), and scalp massage, as a control for physical and social contact inherent in reflexology. Patients receiving reflexology or scalp massage had similar access to the Oncology Health Centres. It was hypothesised that, compared with SIS, women with breast cancer randomised to reflexology or to scalp massage would show reduced immunological and endocrine signs of stress. Immunologically this would include increases in the percentages of $\mathrm{T}$ helper cells expressing Th1 cytokines (i.e., IFN $\gamma$, IL2) and decreases in those expressing Th2 cytokines (i.e., IL4, IL10); increases in the percentage of overall T cells, NK cells, T cytotoxic cells and activated T lymphocytes with no change in B cell or monocyte number; and increases in NK/LAK activity. From a neuroendocrine perspective, it was hypothesised that decreases in cortisol, prolactin and growth hormone levels, along with decreases in the number of lymphocytes expressing their corresponding receptors would be observed.

\section{Materials and methods}

Design, approval and registration. This was a three-armed randomised, controlled trial. Data were collected at three time points: T1 ( $6 \pm 1$ week post breast surgery), T2 and T3 (4 and 10 weeks post completion of CAM, respectively) (Fig. 1).

Ethical approval was obtained from Hull and East Yorkshire Local Research Ethics Committee (reference 01/01/010), and the study was registered with the International 
Table I. Patient characteristics.

\begin{tabular}{|c|c|c|c|c|c|}
\hline & Total $(n=183)$ & Reflexology $(n=60)$ & Massage $(n=61)$ & SIS $(n=62)$ & P-value \\
\hline Mean age (years) & 58.78 & 59.37 & 57.70 & 59.26 & 0.61 \\
\hline SD & 10.31 & 10.47 & 10.12 & 10.23 & \\
\hline Age range & $32-81$ & $32-81$ & $36-76$ & $36-77$ & \\
\hline Ethnicity & & & & & 1.00 \\
\hline Caucasian & 183 & 60 & 59 & 62 & \\
\hline Other & 2 & 0 & 2 & 0 & \\
\hline ER status & & & & & 0.78 \\
\hline Positive & 164 & 53 & 56 & 55 & \\
\hline Negative & 18 & 6 & 5 & 7 & \\
\hline Unknown & 1 & 1 & 0 & 0 & \\
\hline PR status & & & & & 0.65 \\
\hline Positive & 150 & 47 & 52 & 51 & \\
\hline Negative & 30 & 11 & 8 & 11 & \\
\hline Unknown & 3 & 2 & 1 & 0 & \\
\hline T stage & & & & & 0.42 \\
\hline DCIS & 3 & 2 & 0 & 1 & \\
\hline $\mathrm{T} 1$ & 124 & 40 & 43 & 41 & \\
\hline $\mathrm{T} 2$ & 52 & 15 & 18 & 19 & \\
\hline $\mathrm{T} 3$ & 4 & 3 & 0 & 1 & \\
\hline Breast Surgery & & & & & 0.87 \\
\hline Wide local excision & 144 & 47 & 46 & 51 & \\
\hline Quadrantectomy & 1 & 1 & 0 & 0 & \\
\hline Mastectomy & 26 & 8 & 11 & 7 & \\
\hline Mast + reconstruction & 12 & 4 & 4 & 4 & \\
\hline Radiotherapy planned & & & & & 0.31 \\
\hline Yes & 149 & 52 & 50 & 47 & \\
\hline No & 34 & 8 & 11 & 15 & \\
\hline Chemotherapy planned & & & & & 0.88 \\
\hline Yes & 30 & 10 & 11 & 9 & \\
\hline No & 153 & 50 & 50 & 53 & \\
\hline
\end{tabular}

Standard Randomized Controlled Trial Registry (ISRCTN 87652313).

Patients. Women over 18 years of age with early breast cancer [T1, T2 (<3 cm), N0, N1a, M0], awaiting adjuvant therapy, were recruited consecutively after surgery. A diagnostically homogeneous group of patients was chosen to minimise the effects of disease and stage-related variables (Table I) (45). Patients with a previous cancer diagnosis or more advanced disease were not eligible for recruitment, as were those participating in other clinical trials and those suffering from clinically significant cognitive impairment or dementia.

Randomisation. Patients who gave written informed consent $(n=183)$ were randomised to one of three interventions in the Oncology Health Centres at Castle Hill or Princess Royal Hospitals in Hull: self-initiated support (SIS) plus foot reflexology (n=60), SIS plus scalp massage (identical amount of comparator physical and social contact intervention from the same therapists who administered reflexology; $n=61$ ), or SIS alone (treatment as usual; $\mathrm{n}=62$ ) (44).

A permuted block randomisation sequence for each stratum (menopausal status, chemotherapy and radiotherapy) was generated using Graph-Pad (http://www.graphpad.com); block size was 8 and was concealed. The sequences were stored in sealed, opaque, numbered envelopes. Randomisation was carried out remotely at the Clinical Trials Section of the Institute of Rehabilitation, University of Hull. Biological assessments were carried out in a completely blinded manner.

Interventions. Patients randomised to reflexology or massage received 8 sessions at weekly intervals for 8 weeks commencing 7 weeks after surgery. Eight sessions at weekly intervals was chosen on the recommendation of an external consultant who was formerly the Secretary of the Scottish Institute of Reflexology. 
Reflexology was administered by two part-time staff who had been trained to the standards required for membership of the Scottish Institute of Reflexology. Their performance and adherence to the reflexology protocol was monitored at regular intervals during the study by an external consultant experienced in administering reflexology to patients with cancer.

Scalp massage was used as a control for attention, physical contact and non-specific therapist effects. Patients randomised to massage received gentle scalp massage from the same therapists according to a quality assured protocol. Since reflexologists believe that the ears and neck have 'terminals', care was taken to avoid these areas. Scalp massage was chosen, rather than foot or hand massage, because any manipulation or pressure to the feet and hands, according to reflexology theory, will stimulate pressure points and, therefore, will be a weak form of reflexology rather than an appropriate 'placebo'.

Women randomised to SIS were invited to attend, or telephone, one of the Oncology Health Centres whenever they wished. They received 'treatment as usual' in the Centres when they attended, as did those randomised to reflexology or massage. The Oncology Health Centres are staffed by clinical health psychologists and nurses, and provide psychosocial support services for more than 1,500 new patients per year and almost as many new relatives. Emphasis is placed on the prevention of psychological and psychiatric morbidity, and evidence-based psychopharmacological and psychotherapeutic interventions are offered to patients who develop clinically significant problems. Patients can access the service without referral, and appointments are not necessary.

In order to control for practitioner variables, each practitioner saw a similar number of patients in each of the two physical contact arms of the study. As far as possible, each patient had the same therapist throughout, and both treatments were given in the same rooms.

Conventional treatment. All patients underwent conventional treatment according to current best practice (surgery, radiotherapy, chemotherapy and hormone therapy) as clinically indicated.

\section{Biological assays}

Peripheral blood mononuclear cell (PBMC) isolation. Venous blood $(50 \mathrm{ml})$ was collected into syringes containing 1,250 IU heparin from all patients at T1, T2 and T3 and transported to the Centre for Biomedical Research at the University of Hull. PBMCs were isolated using Ficoll-Hypaque (Sigma), density gradient centrifugation (46). The PBMCs were washed with phosphate-buffered saline (PBS; pH 7.4), enumerated using a haemocytometer and assessed for viability by trypan blue exclusion, before resuspension in foetal bovine serum (Invitrogen) containing 10\% (v/v) dimethylsulphoxide (Sigma). Aliquots were then frozen at $1^{\circ} \mathrm{C} / \mathrm{min}$ and stored in liquid nitrogen until use.

Serum separation. Venous blood $(8 \mathrm{ml})$ was collected into serum separator tubes at approximately the same time of day (to control for diurnal variation) for each patient at $\mathrm{T} 1, \mathrm{~T} 2$ and T3. These were incubated at $4^{\circ} \mathrm{C}$ for $30 \mathrm{~min}$ before centrifugation at $1,500 \mathrm{x} g$ for $10 \mathrm{~min}$. The top serum layer was aliquoted and stored at $-80^{\circ} \mathrm{C}$ until ELISA analysis.
Immunophenotyping of peripheral blood mononuclear cells. An aliquot of PBMCs from each of the three time points was resuspended in complete medium [RPMI-1640 medium supplemented with $10 \%(\mathrm{v} / \mathrm{v})$ foetal bovine serum, penicillin $(100 \mathrm{U} / \mathrm{ml}) /$ streptomycin $(100 \mu \mathrm{g} / \mathrm{ml})$ and L-glutamine ( $2 \mathrm{mM})$, all purchased from Invitrogen]. Approximately $2 \times 10^{5}$ PBMCs were labelled with $5 \mu \mathrm{l}(0.1 \mathrm{mg} / \mathrm{ml})$ of one of a panel of fluorescein isothiocyanate (FITC)-conjugated monoclonal antibodies (AbD Serotec, Oxford, UK) for $30 \mathrm{~min}$ in the dark at room temperature. These antibodies were specific for the surface markers: CD2 and CD3 (T cells), CD4 (T helper cells), CD8 (T cytotoxic cells), CD16 and CD56 (NK cells), CD14 (monocytes), CD19 (B cells) and CD25 (activated lymphocytes/regulatory T cells). Purified mouse IgG1-FITC was used as an irrelevant control. Following labelling, the cells were washed with PBS, $\mathrm{pH} 7.4$, containing $0.1 \%(\mathrm{w} / \mathrm{v})$ bovine serum albumin and $10 \mathrm{mM} \mathrm{NaN}_{3}$ (PBS/BSA/azide; Sigma) and recovered by centrifugation before immediate acquisition of 10,000 cells/sample using a FACS Calibur ${ }^{\mathrm{TM}}$ machine (Becton Dickinson, Biosciences, Oxford, UK). Analysis was performed using CellQuest Pro V software (Becton Dickinson) with gates being set around the lymphocytes and the monocytes based on forward scatter/side scatter distribution. Histograms were drawn for each antibody using the lymphocyte gate, except for CD14 which used the monocyte gate. The plots using the irrelevant control were used to set a marker whereby $\leq 3 \%$ of cells were positive with this reagent. To calculate the percentage of specific binding, the irrelevant value was subtracted from the percentage of cells staining with the test antibody.

Th1/Th2 cellular determination. The method used was a modification of that by Jung et al (47). Briefly, PBMCs were incubated for $4 \mathrm{~h}$ at $37^{\circ} \mathrm{C}$ with $5 \% \mathrm{CO}_{2}$ in either activation medium [complete RPMI containing ionomycin $(2 \mu \mathrm{g} / \mathrm{ml})$, brefeldin A $(20 \mu \mathrm{g} / \mathrm{ml})$ and phorbol 12-myristate 13-acetate $(20 \mathrm{ng} / \mathrm{ml})$, all from Sigma] or control medium [complete RPMI containing solely brefeldin A $(20 \mu \mathrm{g} / \mathrm{ml})$ ]. Approximately $2 \times 10^{5}$ PBMCs, were then incubated for $30 \mathrm{~min}$ in the dark with $5 \mu \mathrm{l}(0.1 \mathrm{mg} / \mathrm{ml})$ of FITC labelled monoclonal antibody specific for the surface markers CD3 or CD8; purified mouse IgG1 provided the irrelevant control (AbD Serotec). After incubation, the cells were washed with PBS/ BSA/azide, and fixed using Leucoperm A (AbD Serotec) for $15 \mathrm{~min}$ in the dark. Following further washes, the cells were permeabilised with Leucoperm B before being incubated with $5 \mu \mathrm{l}$ r-phycoerythrin (RPE)-labelled anti-cytokine antibody [IL2, IFN $\gamma$ (Becton Dickinson), IL4, IL10 (AbD Serotec), $0.1 \mathrm{mg} / \mathrm{ml}$ for $30 \mathrm{~min}$ at room temperature in the dark. TNFa (Becton Dickinson) provided a positive activation control, and purified mouse IgG1 provided the negative control. Cells were acquired and analysed as described previously using a FACS Calibur $^{\mathrm{TM}}$. The lymphocyte subset was gated on the basis of forward and side scatter characteristics (Fig. 2A). Stimulated lymphocytes produced Th1 (IL2/IFN $\gamma$ ) and Th2 (IL4/IL10) cytokines (Fig. 2B). CD3 was used as a total lymphocyte marker, and the CD4 fraction was determined by subtraction of the percentage of $\mathrm{CD}^{+}$cells. Unstimulated controls (Fig. 2C) were used to set the quadrants so that $<1 \%$ of these cells were positive for both the surface and the cytokine antibodies (upper right quadrant). 
A

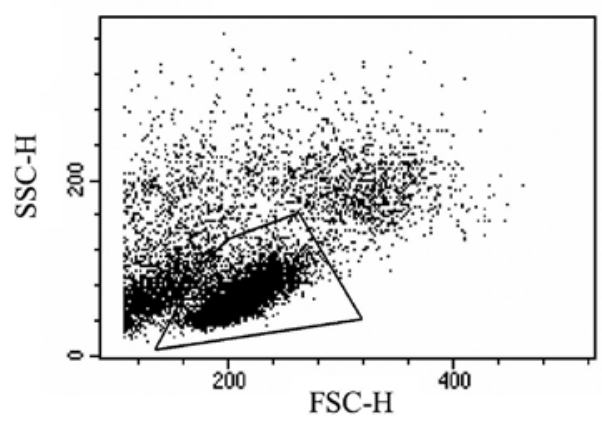

B

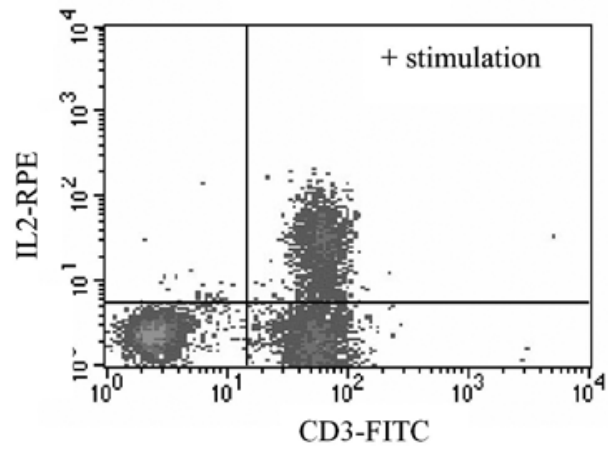

C

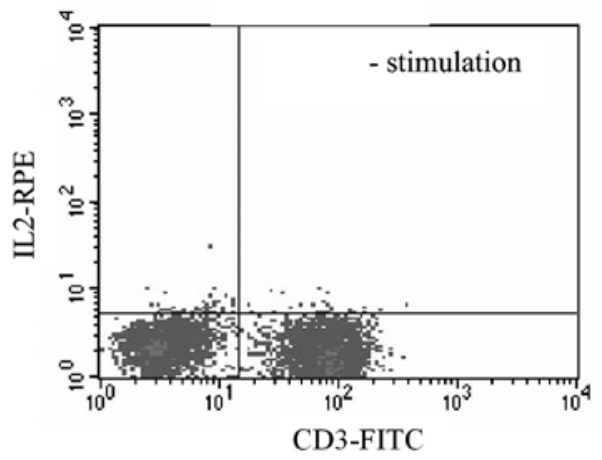

Figure 2. Flow cytometry analysis gating strategies. (A) Forward scatter (FSC-H) and side scatter (SSC-H) characteristics of a PBMC population with the lymphocytes isolated in the quadrilateral gate. Gated-PBMCs labelled with both CD3-FITC and IL2-RPE, with (B) and without (C) prior stimulation with PMA, ionomycin and brefeldin.

$N K$ and LAK cell cytotoxicity. The cytotoxic activity of both NK and LAK cells within the PBMC population was determined using a modification of the Live/Dead Cellmediated cytotoxicity kit (Molecular Probes/Invitrogen) (48). Briefly, 2x10 10 g-phase growing target cells [erythroleukaemic cell line (K562)] for NK and Burkitt lymphoma cell line (Daudi) for LAK] were prelabelled with a green fluorescent membrane dye $\left(\mathrm{DiOC}_{18}(3), 30 \mu \mathrm{M}\right)$ for $1 \mathrm{~h}$ at $37^{\circ} \mathrm{C}$. Once thawed PBMCs were incubated for $48 \mathrm{~h}$ in complete RPMI medium with or without recombinant IL2 $(500 \mathrm{U} / \mathrm{ml}$; AbD Serotec) (49) to stimulate LAK formation and for NK determination respectively; this also allows for the adherence and removal of monocytes. Following washing, viable effector cells were enumerated using trypan blue exclusion, and 1.5 or $3 \times 10^{5}$ cells were added to $3 \times 10^{4}$ target cells to give a $5: 1$ and 10:1 ratio, respectively, in a total volume of $140 \mu \mathrm{l}$. An equal volume of the membrane impermeable dye, propidium iodide (PI; $150 \mu \mathrm{M}$; Sigma), was added to each tube before centrifuging briefly at $1,000 \mathrm{x} \mathrm{g}$ for $1 \mathrm{~min}$ and incubation at $37^{\circ} \mathrm{C}$ for $3.5 \mathrm{~h}$ in a humidified atmosphere. Appropriate controls of target and effector cells alone were also prepared. Following incubation, the cytotoxic activity was analysed by flow cytometry; samples were acquired for $45 \mathrm{sec}$ with no gating and data were obtained for both the green (FL-1, $\left.\mathrm{DiOC}_{18}(3)\right)$ and red (FL-3, PI) fluorescence, as well as forward and side scatter characteristics. Data analysis was performed on dot plots of FL-1 vs. FL-3. Quadrants were set using the appropriate controls to exclude the effector cells from the analysis, and the lysis of target cells was determined from the percentage of cells present in the upper right (UR) quadrant (green and red positive, i.e., dead target cells) divided by the total number of green target cells (UR + LR).

Serum hormone measurements. The hormones prolactin, cortisol and growth hormone were all measured in duplicate, using Enzyme Linked Immunosorbant Assay (ELISA, DRG Instruments GmbH, Germany). All samples from the same patient were analysed on the same ELISA plate to minimise intra-patient variability. Prolactin levels were measured using a standard solid phase sandwich ELISA technique, with a lower detection limit of $2 \mathrm{ng} / \mathrm{ml}$, according to the manufacturer's protocol. Cortisol levels were analysed using a competitive ELISA with a lower detection limit of $2.5 \mathrm{ng} / \mathrm{ml}$, according to the manufacturer's protocol. Growth hormone levels were determined using a solid phase Enzyme Amplified Sensitivity Immunoassay, in which monoclonal antibodies against distinct epitopes of human growth hormone are used to create the sandwich; with a lower detection limit of $0.11 \mu \mathrm{IU} / \mathrm{ml}$. Data for each sample were extracted from the standard curve.

Hormone receptor measurements. Following activation of PBMCs as described above, the cells which were to be used for the detection of the prolactin receptor (PRL-R) and the glucocorticoid receptor (Gluc-R) were permeabilised. PBMCs were then incubated for $30 \mathrm{~min}$ at $4^{\circ} \mathrm{C}$ with $5 \mu \mathrm{l}(1 \mathrm{mg} / \mathrm{ml})$ mouse anti-human antibodies: GH-R unconjugated, Gluc-RFITC conjugated (both AbD Serotec) and PRL-R Ab-1 (B6.2) unconjugated (Neomarkers, Fremont, CA). Purified mouse IgG1 was used as the negative control. Following washing with PBS/BSA/azide unconjugated antibodies were detected using a secondary rabbit anti-mouse F(ab'), IgG:FITC antibody (AbD Serotec) for $30 \mathrm{~min}$ at $4^{\circ} \mathrm{C}$. PBMCs were washed again before flow cytometric analysis.

Statistics. Data were analysed using SPSS v13 for MS Windows. $\alpha$ was set at 0.05 (two-tailed). The comparability of the three groups at baseline (T1; clinical, socio-demographic and psychosocial variables) was assessed using one-way analyses of variance (ANOVA) for continuous variables, and the Chi-square exact test for categorical variables. All data were included in the analyses of categorical variables, and missing data were not inputed, as cohort averages would not have been appropriate.

An intention to treat analysis was carried out (50), and continuous variables were analysed using univariate analyses of covariance (ANCOVA), with age, tumour stage and baseline (T1) values as covariates. To minimise the risk of a Type I error, paired comparisons were only considered when the f-value for the three-group comparison was significant, and Bonferroni corrections were applied for subsequent paired comparisons. Data were log transformed when the distributions differed significantly from the normal. 


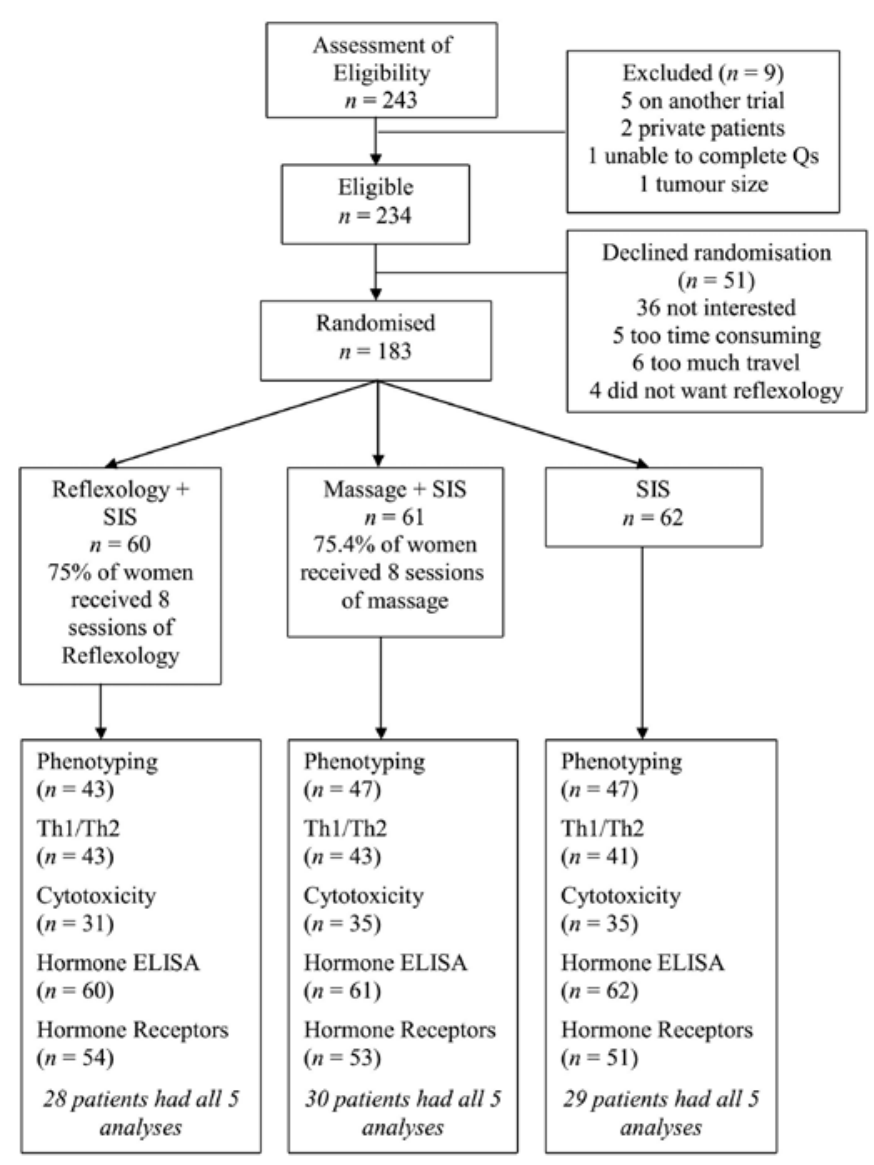

Figure 3. Consort flow chart depicting the recruitment of patients into the three treatment groups and the use of samples in each of the biological assays employed.

\section{Results}

Recruitment and use of samples. A consecutive series of 243 women was assessed for eligibility (Fig. 3). Of the 234 who were eligible, $183(78.2 \%)$ agreed to be randomised. The most common reason for not wishing to participate was lack of interest, often because women expressed a desire to 'get on with their lives'. Four (1.7\%) eligible patients refused randomisation because they did not wish to partake in reflexology.

Sixty patients were randomised to reflexology, 61 to massage and 62 to SIS alone. The characteristics of the women by randomisation are shown in Table I. The three groups did not differ significantly for any of the demographic or clinical variables, including radiotherapy and/or chemotherapy.

The CONSORT diagram (Fig. 3) indicates the samples used for the different biological assays. The number of aliquots of PBMCs obtained from each patient varied, and there were insufficient aliquots from each patient to be used for all techniques. Samples were selected for each analysis on the basis that there were sufficient aliquots of PBMCs present for each of the three time points to enable a full dataset to be collected.

Effects of reflexology and massage on phenotypic distribution of PBMCs. Flow cytometry was used to determine the changes which occurred in the distribution of the mononuclear cell populations (Table II). At T3, ANCOVA showed that the

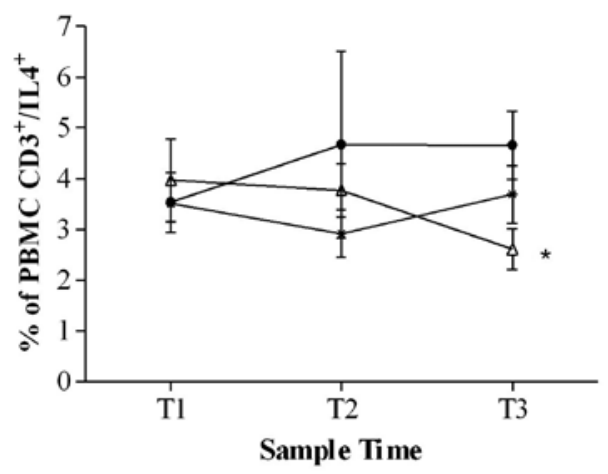

B

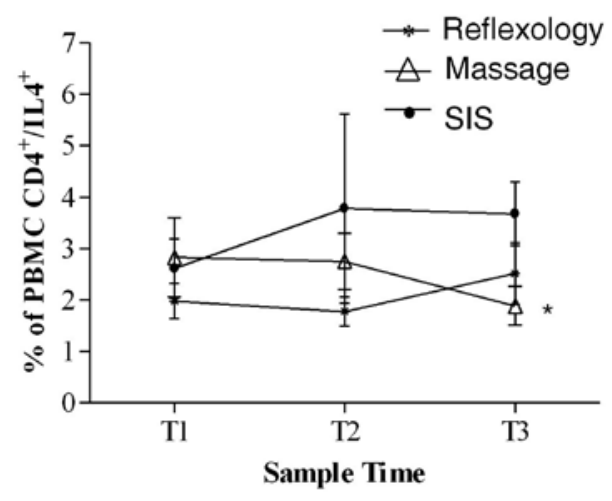

C

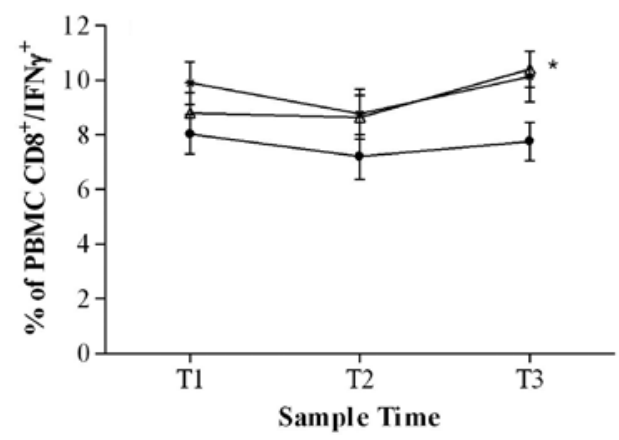

Figure 4. Percentage of PBMCs from patients with early breast cancer positive for (A) CD3/IL4 (B) CD4/IL4 and (C) CD8/IFN $\gamma$, at T1, T2 and T3. *Significant differences between groups $(\mathrm{p}<0.05)$.

percentage of $\mathrm{CD} 25^{+}$lymphocytes in the patients receiving massage was significantly higher than for those in the SIS group $(\mathrm{p}=0.05)$. No significant between-group differences were found for the remainder of the phenotypic markers.

The percentages of NK, B cells, $\mathrm{CD}^{+}$and $\mathrm{CD} 4^{+} \mathrm{T}$ cells were very similar to those previously reported both pre- and post-psychosocial intervention by Carlson et al in a cohort of patients with either breast or prostate cancer (51).

Effects of reflexology and massage on Th1/Th2 cell balance in PBMCs. Table III shows the results from the flow cytometry method used to determine the percentage of lymphocytes producing Th1 (IL2/IFN $\gamma$ ) and Th2 (IL4/IL10) cytokines. ANCOVA showed a significantly lower percentage of $\mathrm{CD}^{+}$ cells expressing IL4 at T3 in the massage patients compared with the SIS patients ( $\mathrm{p}=0.02$, Fig. $4 \mathrm{~A}$ ). The same was true in the $\mathrm{CD} 4^{+}$subset of $\mathrm{T}$ cells expressing IL4 which mirrored the results of the $\mathrm{CD}^{+}$cells (Fig. 4B; $\mathrm{p}=0.02$ ). 
Table II. Mean percentage of PBMCs from early breast cancer patients expressing phenotypic markers at T2 and T3.

$\mathrm{T} 2$

\begin{tabular}{|c|c|c|c|c|c|c|c|}
\hline & $\begin{array}{c}\text { A } \\
\text { Reflexology }+ \text { SIS }\end{array}$ & $\begin{array}{c}\text { B } \\
\text { Massage }+ \text { SIS }\end{array}$ & $\begin{array}{c}\text { C } \\
\text { SIS }\end{array}$ & $\begin{array}{c}\text { A vs. B vs. C } \\
\text { f-test } \\
\text { p-value }\end{array}$ & $\begin{array}{l}\text { A vs. B } \\
\text { f-test } \\
\text { p-value }\end{array}$ & $\begin{array}{c}\text { A vs. C } \\
\text { f-test } \\
\text { p-value }\end{array}$ & $\begin{array}{c}\text { B vs. C } \\
\text { f-test } \\
\text { p-value }\end{array}$ \\
\hline CD3 & $69.6 \pm 2.8$ & $70.2 \pm 2.6$ & $66.3 \pm 2.7$ & 0.56 & 1.0 & 1.00 & 0.93 \\
\hline $\mathrm{CD} 2$ & $75.3 \pm 3.6$ & $75.0 \pm 3.5$ & $70.2 \pm 3.5$ & 0.51 & 1.0 & 0.92 & 0.97 \\
\hline CD4 & $47.0 \pm 2.3$ & $45.7 \pm 2.2$ & $44.2 \pm 2.2$ & 0.69 & 1.0 & 1.00 & 1.00 \\
\hline CD8 & $20.6 \pm 1.1$ & $19.7 \pm 1.1$ & $22.5 \pm 1.1$ & 0.17 & 1.0 & 0.64 & 0.19 \\
\hline CD16 & $16.7 \pm 1.2$ & $16.8 \pm 1.1$ & $17.6 \pm 1.1$ & 0.83 & 1.0 & 1.00 & 1.00 \\
\hline CD56 & $9.9 \pm 1.2$ & $11.1 \pm 1.1$ & $11.4 \pm 1.1$ & 0.62 & 1.0 & 1.00 & 1.00 \\
\hline CD14 & $7.8 \pm 1.1$ & $8.2 \pm 1.1$ & $8.4 \pm 1.1$ & 0.93 & 1.0 & 1.00 & 1.00 \\
\hline CD19 & $6.5 \pm 0.8$ & $7.4 \pm 0.8$ & $7.5 \pm 0.8$ & 0.63 & 1.0 & 1.00 & 1.00 \\
\hline CD25 & $7.3 \pm 1.0$ & $6.5 \pm 1.0$ & $5.3 \pm 1.0$ & 0.36 & 1.0 & 0.47 & 1.00 \\
\hline
\end{tabular}

T3

\begin{tabular}{|c|c|c|c|c|c|c|c|}
\hline CD3 & $71.8 \pm 2.0$ & $69.8 \pm 1.9$ & $69.9 \pm 1.9$ & 0.71 & 1.00 & 1.00 & 1.00 \\
\hline CD2 & $75.8 \pm 3.1$ & $74.7 \pm 2.9$ & $74.7 \pm 2.9$ & 0.96 & 1.00 & 1.00 & 1.00 \\
\hline CD4 & $47.8 \pm 1.8$ & $48.0 \pm 1.8$ & $47.5 \pm 1.8$ & 1.00 & 1.00 & 1.00 & 1.00 \\
\hline CD8 & $21.8 \pm 1.5$ & $21.9 \pm 1.4$ & $21.1 \pm 1.4$ & 0.92 & 1.00 & 1.00 & 1.00 \\
\hline CD16 & $18.2 \pm 1.8$ & $20.2 \pm 1.8$ & $17.8 \pm 1.7$ & 0.59 & 1.00 & 1.00 & 1.00 \\
\hline CD56 & $13.5 \pm 1.7$ & $14.8 \pm 1.6$ & $13.2 \pm 1.6$ & 0.76 & 1.00 & 1.00 & 1.00 \\
\hline CD14 & $9.3 \pm 1.0$ & $9.3 \pm 1.0$ & $8.1 \pm 1.0$ & 0.60 & 1.00 & 1.00 & 1.00 \\
\hline CD19 & $6.8 \pm 0.9$ & $9.3 \pm 0.9$ & $7.4 \pm 0.9$ & 0.11 & 0.14 & 1.00 & 0.38 \\
\hline CD25 & $10.1 \pm 1.5$ & $10.8 \pm 1.5$ & $5.7 \pm 1.5$ & $0.03^{\mathrm{a}}$ & 1.00 & 0.12 & $0.05^{\mathrm{a}}$ \\
\hline
\end{tabular}

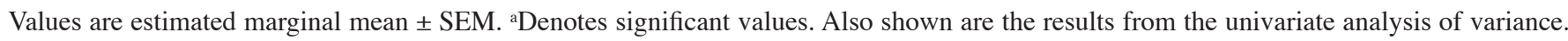
All values are adjusted for baseline.

At T3, ANCOVA showed that a significantly higher percentage of $\mathrm{CD}^{+}$cells were expressing IFN $\gamma$ in the massage group compared with the SIS group ( $\mathrm{p}=0.02$, Fig. 4C). No significant between-group differences were found for any of the other $\mathrm{T}$ cell subsets expressing Th1- or Th2-like cytokines.

Effects of reflexology and massage on the cytotoxic activity of PBMCs. The NK and LAK cell activity was determined at effector:target ratios of 5:1 and 10:1 using a flow cytometrybased method. These ratios were chosen since they provided the most reproducible results in initial studies and spared sufficient PBMCs for use in other experiments. There were no significant between-group differences in the cytotoxic activity of either NK or LAK cells at any time point (Table IV).

Effects of reflexology and massage on serum hormone levels and receptor expression in PBMCs. Analysis of the serum hormones or hormone receptors (cortisol, prolactin and growth hormone) also found no significant between-group differences (Tables V and VI). All the values obtained for the serum hormone concentrations were within the normal range described in the manufacturer's protocols.

\section{Discussion}

This study of 183 women with early breast cancer is the largest randomised, controlled trial of reflexology reported to date. Over $78 \%$ of a consecutive series of eligible women consented to participate in the study, which suggests that the results are representative and generalisable.

Scalp massage was chosen to control for the effects of extra physical and social contact, both of which could enhance relaxation and act as a buffer against stress. Massage is often combined with aromatherapy, and beneficial effects have been reported previously (52). Research designed to evaluate the relative contributions of the extra physical and social contact would be of considerable interest, especially in light of this study's findings.

Imbalances in proportions of immune cells in patients with cancer have been previously documented $(53,54)$, resulting in generalised and/or specific immunosuppression. Here the only change observed in lymphocyte subsets was the increase over time in the percentage of $\mathrm{CD} 25^{+}$cells from patients receiving either massage or reflexology, and by T3 the difference was significantly greater in the massage patients compared with the SIS group. The current finding is 
Table III. Mean percentage of Th1 (IL2, IFN $\gamma$ ) and Th2-like (IL4, IL10) T (CD3), cytotoxic (CD8) and helper (CD4) cell proportions in PBMCs from breast cancer patients at T2 and T3.

$\mathrm{T} 2$

\begin{tabular}{|c|c|c|c|c|c|c|c|}
\hline & $\begin{array}{c}\text { A } \\
\text { Reflexology }+ \text { SIS }\end{array}$ & $\begin{array}{c}\text { B } \\
\text { Massage }+ \text { SIS }\end{array}$ & $\begin{array}{c}\text { C } \\
\text { SIS }\end{array}$ & $\begin{array}{c}\text { A vs. B vs. C } \\
\text { f-test } \\
\text { p-value }\end{array}$ & $\begin{array}{c}\text { A vs. B } \\
\text { f-test } \\
\text { p-value }\end{array}$ & $\begin{array}{l}\text { A vs. C } \\
\text { f-test } \\
\text { p-value }\end{array}$ & $\begin{array}{c}\text { B vs. C } \\
\text { f-test } \\
\text { p-value }\end{array}$ \\
\hline CD3/IL2 & $23.5 \pm 1.5$ & $25.2 \pm 1.5$ & $22.5 \pm 1.6$ & 0.45 & 1.00 & 1.00 & 0.64 \\
\hline $\mathrm{CD} 3 / \mathrm{IFN} \gamma$ & $19.3 \pm 1.1$ & $20.3 \pm 1.1$ & $17.2 \pm 1.2$ & 0.17 & 1.00 & 0.61 & 0.19 \\
\hline CD3/IL4 & $2.9 \pm 1.1$ & $3.9 \pm 1.1$ & $4.9 \pm 1.2$ & 0.48 & 1.00 & 0.69 & 1.00 \\
\hline CD3/IL10 & $1.2 \pm 0.4$ & $1.5 \pm 0.4$ & $0.9 \pm 0.4$ & 0.63 & 1.00 & 1.00 & 1.00 \\
\hline CD8/IL2 & $2.6 \pm 0.2$ & $2.8 \pm 0.2$ & $2.5 \pm 0.2$ & 0.59 & 1.00 & 1.00 & 0.93 \\
\hline $\mathrm{CD} 8 / \mathrm{IFN} \gamma$ & $8.1 \pm 0.6$ & $9.2 \pm 0.6$ & $8.0 \pm 0.6$ & 0.26 & 0.51 & 1.00 & 0.45 \\
\hline CD8/IL4 & $0.8 \pm 0.17$ & $1.2 \pm 0.2$ & $1.0 \pm 0.2$ & 0.21 & 0.25 & 0.92 & 1.00 \\
\hline CD8/IL10 & $0.4 \pm 0.15$ & $0.4 \pm 0.2$ & $0.5 \pm 0.2$ & 0.82 & 1.00 & 1.00 & 1.00 \\
\hline CD4/IL2 & $20.9 \pm 1.4$ & $22.5 \pm 1.4$ & $20.0 \pm 1.5$ & 0.46 & 1.00 & 1.00 & 0.66 \\
\hline $\mathrm{CD} 4 / \mathrm{IFN} \gamma$ & $10.7 \pm 0.8$ & $11.2 \pm 0.8$ & $9.6 \pm 0.8$ & 0.32 & 1.00 & 0.87 & 0.43 \\
\hline CD4/IL4 & $1.8 \pm 1.1$ & $2.9 \pm 1.2$ & $4.1 \pm 1.2$ & 0.38 & 1.00 & 0.49 & 1.00 \\
\hline CD4/IL10 & $0.7 \pm 0.4$ & $1.1 \pm 0.4$ & $0.6 \pm 0.4$ & 0.57 & 1.00 & 1.00 & 1.00 \\
\hline
\end{tabular}

T3

\begin{tabular}{|c|c|c|c|c|c|c|c|}
\hline CD3/IL2 & $26.7 \pm 1.7$ & $26.7 \pm 1.8$ & $26.0 \pm 1.8$ & 0.94 & 1.00 & 1.00 & 1.00 \\
\hline $\mathrm{CD} 3 / \mathrm{IFN} \gamma$ & $20.5 \pm 1.0$ & $21.2 \pm 1.1$ & $19.5 \pm 1.1$ & 0.52 & 1.00 & 1.00 & 0.76 \\
\hline CD3/IL4 & $3.7 \pm 0.6$ & $2.5 \pm 0.6$ & $4.8 \pm 0.6$ & $0.03^{\mathrm{a}}$ & 0.44 & 0.56 & $0.02^{\mathrm{a}}$ \\
\hline CD3/IL10 & $0.9 \pm 0.2$ & $0.8 \pm 0.2$ & $0.9 \pm 0.2$ & 0.72 & 1.00 & 1.00 & 1.00 \\
\hline CD8/IL2 & $3.0 \pm 0.2$ & $2.8 \pm 0.3$ & $2.5 \pm 0.3$ & 0.48 & 1.00 & 0.70 & 1.00 \\
\hline $\mathrm{CD} 8 / \mathrm{IFN} \gamma$ & $9.4 \pm 0.6$ & $10.6 \pm 0.6$ & $8.3 \pm 0.6$ & $0.03^{\mathrm{a}}$ & 0.45 & 0.59 & $0.02^{\mathrm{a}}$ \\
\hline CD8/IL4 & $1.7 \pm 0.3$ & $1.0 \pm 0.3$ & $1.0 \pm 0.3$ & 0.07 & 0.12 & 0.17 & 1.00 \\
\hline CD8/IL10 & $0.3 \pm 0.1$ & $0.2 \pm 0.1$ & $0.3 \pm 0.1$ & 0.86 & 1.00 & 1.00 & 1.00 \\
\hline CD4/IL2 & $24.9 \pm 1.6$ & $24.1 \pm 1.7$ & $23.5 \pm 1.7$ & 0.82 & 1.00 & 1.00 & 1.00 \\
\hline $\mathrm{CD} 4 / \mathrm{IFN} \gamma$ & $11.6 \pm 0.7$ & $11.1 \pm 0.7$ & $11.2 \pm 0.7$ & 0.89 & 1.00 & 1.00 & 1.00 \\
\hline CD4/IL4 & $2.7 \pm 0.6$ & $1.7 \pm 0.6$ & $3.7 \pm 0.6$ & $0.02^{\mathrm{a}}$ & 0.9 & 0.20 & $0.02^{\mathrm{a}}$ \\
\hline CD4/IL10 & $0.8 \pm 0.2$ & $0.6 \pm 0.2$ & $0.7 \pm 0.2$ & 0.85 & 1.00 & 1.00 & 1.00 \\
\hline
\end{tabular}

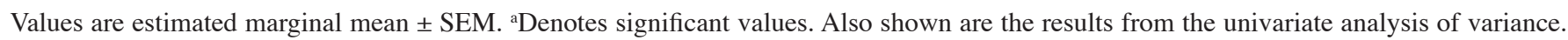
All values are adjusted for baseline.

consistent with previous results from the present group who reported that the percentage of $\mathrm{CD} 25^{+}$cells was significantly greater in breast cancer patients receiving relaxation training and guided imagery compared with SIS (38). Research in the 1990s showed that activated CD25 ${ }^{+} \mathrm{T}$ lymphocytes could induce tumour cell death and play a role in inhibiting tumour growth in animal models $(55,56)$, suggesting that the enhanced percentage of $\mathrm{CD} 25^{+}$cells in the present study could be beneficial to breast cancer patients. However, more recent work has focused intensely on a subpopulation of $\mathrm{CD} 25^{+}$ cells, namely $\mathrm{CD} 4{ }^{+} \mathrm{CD} 25^{+}$cells, now commonly known as $\mathrm{T}$ regulatory cells. These cells are frequently increased in patients with several types of malignancies and are correlated positively with disease stage and poor prognosis (57). They also play a role in immune evasion mechanisms employed by cancer cells (58), and can decrease the activity of $\mathrm{CD} 8^{+} \mathrm{T}$ cells and NK cells (59). Further characterisation of the CD25+ subpopulations was not possible due to the lack of cells for the analysis of $\mathrm{T}$ regulatory cell markers such as FoxP3, GITR and CD127.

Previously, a small scale study of breast cancer patients found increases in lymphocyte and NK cell numbers over time following massage therapy and progressive muscle relaxation (60). Hypnotic guided imagery in breast cancer patients has also been reported to increase absolute NK cell numbers (61), but this increase was not maintained after a 3-month follow-up. In the current study, no between-group differences were observed in NK cell numbers, and changes in CD25+ lymphocytes were only apparent at 6 months.

In support of a delayed NK cell response, a randomised controlled study by Fawzy et al (43) evaluating the effect of a 6-week structured psychiatric group intervention in melanoma patients who had undergone surgery, demonstrated an increase in absolute NK and large granular lymphocyte numbers which 
Table IV. Mean percentage K562 and Daudi cell death induced by NK and LAK cells respectively, in PBMCs from breast cancer patients at 5:1 and 10:1 (effector:target) ratios at T2 and T3.

$\mathrm{T} 2$

\begin{tabular}{|c|c|c|c|c|c|c|c|}
\hline Ratio & $\begin{array}{c}\text { A } \\
\text { Reflexology }+ \text { SIS }\end{array}$ & $\begin{array}{c}\text { B } \\
\text { Massage }+ \text { SIS }\end{array}$ & $\begin{array}{c}\mathrm{C} \\
\text { SIS }\end{array}$ & $\begin{array}{c}\text { A vs. B vs. C } \\
\text { f-test } \\
\text { p-value }\end{array}$ & $\begin{array}{c}\text { A vs. B } \\
\text { f-test } \\
\text { p-value }\end{array}$ & $\begin{array}{c}\text { A vs. C } \\
\text { f-test } \\
\text { p-value }\end{array}$ & $\begin{array}{c}\text { B vs. C } \\
\text { f-test } \\
\text { p-value }\end{array}$ \\
\hline NK & $5.2 \pm 1.1$ & $6.1 \pm 1.0$ & $5.5 \pm 1.1$ & 0.83 & 1.00 & 1.00 & 1.00 \\
\hline $10: 1$ & $5.4 \pm 1.4$ & $7.8 \pm 1.3$ & $7.6 \pm 1.8$ & 0.42 & 0.65 & 1.00 & 1.00 \\
\hline LAK $\quad 5: 1$ & $5.8 \pm 0.9$ & $4.6 \pm 0.9$ & $6.2 \pm 1.0$ & 0.44 & 1.00 & 1.00 & 0.69 \\
\hline LAK 10:1 & $5.8 \pm 1.6$ & $4.5 \pm 1.4$ & $5.2 \pm 1.8$ & 0.82 & 1.00 & 1.00 & 1.00 \\
\hline
\end{tabular}

T3

\begin{tabular}{lrlllllll}
\hline NK & $5: 1$ & $5.5 \pm 1.1$ & $5.5 \pm 1.1$ & $8.2 \pm 1.1$ & 0.12 & 1.0 & 0.22 & 0.23 \\
NK & $10: 1$ & $5.5 \pm 1.4$ & $5.3 \pm 1.3$ & $9.8 \pm 1.6$ & 0.09 & 1.0 & 0.16 & 0.12 \\
LAK & $5: 1$ & $5.3 \pm 1.0$ & $4.9 \pm 1.0$ & $6.2 \pm 1.0$ & 0.62 & 1.0 & 1.00 & 1.00 \\
LAK & $10: 1$ & $5.3 \pm 1.6$ & $6.2 \pm 1.6$ & $7.1 \pm 1.8$ & 0.78 & 1.0 & 1.00 & 1.00 \\
\hline
\end{tabular}

Values are estimated marginal mean \pm SEM. Also shown are the results from the univariate analysis of variance. All values are adjusted for baseline.

Table V. Mean concentration of cortisol (ng/ml), prolactin $(\mathrm{ng} / \mathrm{ml})$ and growth hormone $(\mu \mathrm{IU} / \mathrm{ml})$ in serum from breast cancer patients at $\mathrm{T} 2$ and $\mathrm{T} 3$.

$\mathrm{T} 2$

\begin{tabular}{lccccccc}
\hline $\begin{array}{l}\text { Serum } \\
\text { hormones }\end{array}$ & $\begin{array}{c}\text { A } \\
\text { Reflexology + SIS }\end{array}$ & Massage + SIS & SIS & $\begin{array}{c}\text { A vs. B vs. C } \\
\text { f-test } \\
\text { p-value }\end{array}$ & $\begin{array}{c}\text { A vs. B } \\
\text { f-test } \\
\text { p-value }\end{array}$ & $\begin{array}{c}\text { A vs. C } \\
\text { f-test } \\
\text { p-value }\end{array}$ & $\begin{array}{c}\text { B vs. C } \\
\text { f-test } \\
\text { p-value }\end{array}$ \\
\hline Cortisol & $123.2 \pm 5.6$ & $110.4 \pm 5.6$ & $117.9 \pm 5.8$ & 0.28 & 0.33 & 1.00 & 1.00 \\
Prolactin & $6.4 \pm 1.1$ & $5.3 \pm 1.1$ & $4.3 \pm 1.1$ & 0.39 & 1.00 & 0.51 & 1.00 \\
Growth & $2.6 \pm 0.5$ & $1.5 \pm 0.5$ & $2.5 \pm 0.5$ & 0.25 & 0.40 & 1.00 & 0.50 \\
hormone & & & & & & &
\end{tabular}

T3

\begin{tabular}{|c|c|c|c|c|c|c|c|}
\hline Cortisol & $131.7 \pm 6.3$ & $117.8 \pm 6.1$ & $122.5 \pm 6.3$ & 0.29 & 0.36 & 0.91 & 1.00 \\
\hline Prolactin & $6.3 \pm 0.9$ & $4.4 \pm 0.9$ & $4.7 \pm 0.9$ & 0.27 & 0.39 & 0.61 & 1.00 \\
\hline $\begin{array}{l}\text { Growth } \\
\text { hormone }\end{array}$ & $3.0 \pm 1.1$ & $3.2 \pm 1.0$ & $3.6 \pm 1.1$ & 0.92 & 1.00 & 1.00 & 1.00 \\
\hline
\end{tabular}

Values are estimated marginal mean \pm SEM. Also shown are the results from the univariate analysis of variance. All values are adjusted for baseline.

only became evident at the 6-month follow-up. Other studies, which have demonstrated no changes in overall lymphocyte cell numbers and subsets, have usually had relatively brief follow-up periods (51). In contrast, van der Pompe et al (36) demonstrated lower percentages of NK, CD8 and CD4 cells following 13 weeks of experiential-existential group psychotherapy in breast cancer patients who had undergone surgery at least 4 months prior to the study. Thus, changes in lymphocyte subsets may well occur following a CAM intervention, but effects could be delayed most probably due to the suppressive effects associated with the proximity to surgery and adjuvant chemotherapy and/or radiotherapy treatments.

Natural cytotoxicity can be reduced in certain types of cancer patients, and conventional treatments can suppress this further (62); however, the ability of NK and LAK cells to kill human cancer cells efficiently ex vivo has led to much work 
Table VI. Mean percentages of PBMCs from breast cancer patients expressing the receptors for cortisol (Gluc-R), prolactin (PRL-R) and growth hormone (GH-R) at T2 and T3.

$\mathrm{T} 2$

\begin{tabular}{lccccccc}
\hline $\begin{array}{l}\text { Hormone } \\
\text { receptors }\end{array}$ & $\begin{array}{c}\text { A } \\
\text { Reflexology + SIS }\end{array}$ & $\begin{array}{c}\text { B } \\
\text { Massage + SIS }\end{array}$ & $\begin{array}{c}\text { C } \\
\text { SIS }\end{array}$ & $\begin{array}{c}\text { A vs. B vs. C } \\
\text { f-test } \\
\text { p-value }\end{array}$ & $\begin{array}{c}\text { A vs. B } \\
\text { f-test } \\
\text {-value }\end{array}$ & $\begin{array}{c}\text { A vs. C } \\
\text { f-test } \\
\text { p-value }\end{array}$ & $\begin{array}{c}\text { B vs. C } \\
\text { f-test } \\
\text {-value }\end{array}$ \\
\hline Gluc-R & $72.6 \pm 2.8$ & $77.3 \pm 2.8$ & $68.2 \pm 3.1$ & 0.09 & 0.70 & 0.89 \\
PRL-R & $70.8 \pm 2.8$ & $63.7 \pm 2.8$ & $67.5 \pm 3.1$ & 0.21 & 0.23 & 1.00 & 1.00 \\
GH-R & $1.8 \pm 0.7$ & $1.4 \pm 0.7$ & $1.8 \pm 0.8$ & 0.91 & 1.00 & 1.00 & 1.00
\end{tabular}

T3

\begin{tabular}{|c|c|c|c|c|c|c|c|}
\hline Gluc-R & $73.9 \pm 3.2$ & $73.9 \pm 3.0$ & $74.4 \pm 3.2$ & 1.00 & 1.00 & 1.00 & 1.00 \\
\hline PRL-R & $74.0 \pm 3.1$ & $66.5 \pm 2.9$ & $67.4 \pm 3.0$ & 0.16 & 0.22 & 0.37 & 1.00 \\
\hline GH-R & $1.1 \pm 1.0$ & $3.4 \pm 0.9$ & $1.7 \pm 1.0$ & 0.23 & 0.30 & 1.00 & 0.71 \\
\hline
\end{tabular}

Values are estimated marginal mean \pm SEM. Also shown are the results from the univariate analysis of variance. All values are adjusted for baseline.

assessing their potential as a form of immunotherapy $(63,64)$. Using effector:target ratios of 5:1 and 10:1 we found no significant differences between groups for the interventions, which is in agreement with other studies $(61,43)$. This suggests that the mechanism by which reflexology and massage enhance quality of life does not directly involve the increased activation of the cytotoxic NK and LAK cells, but could however be mediated by increased cell number. Numerous effector:target ratios have been used ranging from 1:1 to 50:1 $(61,65)$, however if ratios above 10:1 were used in the current study there would have been insufficient cells to study the breadth of immune parameters.

The most notable findings with respect to the Th1/Th2 balance were that, in the massage patients at $\mathrm{T} 3$, there was a significantly lower percentage of both $\mathrm{CD}^{+}$and $\mathrm{CD}^{+}$cells expressing the Th 2 cytokine IL4 compared with SIS, and this was accompanied by a significant increase in the percentage of $\mathrm{CD}^{+}$cells expressing the Th1 cytokine IFN $\gamma$. The fact that different cell populations are both changing in a manner that produces a Th1-like response is highly intriguing. It also suggests that the commonly observed increase in circulating IL-10 in cancer patients, produced by Th2-like cells, is a later phenomenon caused as a consequence of changes in other $\mathrm{T}$ cell subsets. Overall the results strongly suggest that there has been some form of rebalancing of the Th1/Th2 system in the patients receiving scalp massage.

In the present study, IL4 proved to be a good marker for Th2-like cells; however, IL10 was detected at very low levels, in accordance with previous studies, which found percentages of approximately $0.2-0.6 \%$ in caregivers and controls (66). A further practical limitation of the study, in addition to the lack of PBMCs, was that the neuroendocrine factors were only measured at a single time-point, and it is well known that some of these have pronounced circadian rhythms. This was a practical constraint due to the inability to take multiple blood or other biological samples in a day. However, variations were minimized by taking blood at similar time-points. Other studies have commonly used saliva, an easier fluid to sample; however, this was not available in the current trial.

The practical limitations described above are possibly responsible for the fact that no effect of massage or reflexology was observed on hormone concentrations or receptor levels. These results contrast with previous studies in cancer patients which demonstrated that psychotherapeutic treatment and greater social support can normalise or reduce cortisol levels, as well as lowering prolactin levels. In breast and colorectal cancer patients, mindfulness-based stress reduction has not only been shown to improve quality of life, but was also associated with decreased afternoon cortisol levels (67).

A quality of life study conducted on the same patients showed a high level of satisfaction and compliance with both reflexology and massage, and demonstrated that at T2, massage improved quality of life, but reflexology did not have an effect until T3 (68). This is partly in accordance with the immune factors as many did not become significant until the final endpoint (T3). The primary end point for the quality of life study, T2, was chosen as 4 weeks after the end of the final session of reflexology or massage. The effectiveness of the support provided during SIS could provide one explanation for the lack of differences found between the groups, as we have previously shown that the provision of a fully integrated oncology health service with drop-in facilities and trained staff to identify and resolve concerns immediately, is associated with very low levels of psychosocial morbidity in women with locally advanced breast cancer (42).

This study has demonstrated that in women with early breast cancer, scalp massage, the active control condition, but not reflexology, the treatment of interest, administered according to standardised protocols induced a range of immunological changes including an increase in the percentage of $\mathrm{CD} 25^{+}$ cells and a shift towards a Th1-like response. Further studies in other cancer populations should now be undertaken, and 
attempts made to evaluate the underlying biopsychosocial mechanisms, as well as the possible clinical consequences of these changes.

\section{Acknowledgements}

Funding support for the trial was provided by the National Health Service, National Cancer Research and Development Programme NCP2/X229. Hull and East Yorkshire Hospitals NHS Trust Endowments and the University of Hull provided support for the laboratory work. We wish to thank all the patients who participated, members of the Trial Management Group and the NHS R\&D Cancer Programme. We also wish to acknowledge the therapists Mrs. A. Grantham and Mrs. S. Waters and the Clinical and Research Nurse Specialists (Behavioural Oncology) in the Oncology Health Service (Mrs. J. Bateman, Mrs. K. Ellwood, Mrs. C. Hebblewhite, Mrs. T. Hope and Mr. M. Lines). We are grateful to the clinicians who referred patients; in addition to those clinicians listed in the Trial Management Group, we wish to acknowledge the help of Dr Sunil K. Upadhyay and Dr A. Abdel-Hamid. Trial Management Group (excluding authors): Professor M.J. Lind, Foundation Professor of Oncology, University of Hull; Dr A. Chaturvedi, Consultant Clinical Oncologist, Hull and East Yorkshire Hospitals NHS Trust; Mr. J. Wood, Divisional Manager (Cancer Services), Hull and East Yorkshire Hospitals NHS Trust; Mrs. J. Jenkinson, Breast Care Clinical Nurse Specialist, Hull and East Yorkshire Hospitals NHS Trust; Mr. W. Brown, Superintendent Radiographer, Hull and East Yorkshire Hospitals NHS Trust; Professor J.R.T. Monson, Professor of Surgery, University of Hull; Professor P.J. Drew, Professor in Tissue Engineering and Wound Healing, Hull York Medical School; Mr. J. Fox, Consultant Breast Surgeon, Hull and East Yorkshire Hospitals NHS Trust; Mr. T. Mahapatra, Consultant Breast Surgeon, Hull and East Yorkshire Hospitals NHS Trust; Ms P. McManus, Consultant Breast Surgeon, Hull and East Yorkshire Hospitals NHS Trust.

\section{References}

1. Cancer Research UK: News and Resources (http://info.cancerresearchuk.org/cancerstats/types/breast/incidence).

2. Zabora J, Brintzenhofenszoc K, Curbow B, Hooker $\mathrm{C}$ and Piantadosi S: The prevalence of psychological distress by cancer site. Psychooncology 10: 19-28, 2001.

3. Hall A, A'Hern R and Fallowfield L: Are we using appropriate self-report questionnaires for detecting anxiety and depression in women with early breast cancer? Eur J Cancer 35: 79-85, 1999.

4. Burgess C, Cornelius V, Love S, Graham J, Richards M and Ramirez A: Depression and anxiety in women with early breast cancer: five year observational cohort study. BMJ 330: 702, 2005.

5. Cassileth BR and Vickers AJ: High prevalence of complementary therapy and alternative medicine use among cancer patients. J Clin Oncol 23: 2590-2592, 2005.

6. Molassiotis A, Fernadez-Ortega P, Pud D, et al: Use of complementary and alternative medicine in cancer patients: a European survey. Ann Oncol 16: 655-663, 2005.

7. Ernst AR and White A: The BBC survey of complementary medicine use in the UK. Complement Ther Med 8: 32-36, 2000.

8. Matthews AK, Sellergren MA, Huo D, List M and Fleming G: Complementary and alternative medicine use among breast cancer survivors. J Altern Complement Med 13: 555-562, 2007.

9. Corner J, Cawley N and Hildebrand S: An evaluation of the use of massage and essential oils on the wellbeing of cancer patients. Int J Palliat Nurs 1: 67-73, 1995.
10. Elenkov IJ and Chrousos GP: Stress system - Organization, physiology and immunoregulation. Neuroimmunomodulation 13: $257-267,2006$

11. Walker LG, Green VL, Greenman J, Walker A and Sharp DM: PNI and Chronic Malignant Disease: Cancer. In: Human Psychoneuroimmunology (PNI). Irwin M and Vedhara K (eds). Oxford University Press, UK, pp137-163, 2005.

12. Herbert TB and Cohen S: Stress and immunity in humans: a meta-analytic review. Psychosom Med 55: 364-379, 1993.

13. Segerstrom SC and Miller GE: Psychological stress and the immune system: a meta-analytic study of 30 years of enquiry. Psychol Bull 130: 601-630, 2004.

14. Ghiringhelli F, Menard C, Puig PE, et al: Metronomic cyclophosphamide regimen selectively depletes $\mathrm{CD} 4{ }^{+} \mathrm{CD} 25^{+}$regulatory $\mathrm{T}$ cells and restores $\mathrm{T}$ and $\mathrm{NK}$ effector functions in end stage cancer patients. Cancer Immunol Immunother 56: 641-648, 2007.

15. Spiegel D and Giese-Davis J: Depression and cancer: mechanisms and disease progression. Biol Psychiatry 54: 269-282, 2003.

16. Yang EV and Glaser R: Stress-induced immunomodulation: implications for tumorigenesis. Brain Behav Immun 17 (Suppl 1): 37-40, 2003.

17. Penninx BW, Guralnik JM, Pahor M, Ferrucci L, Cerhan JR, Wallace RB and Havlik RJ: Chronically depressed mood and cancer risk in older persons. J Natl Cancer Inst 90: 1888-1893, 1998.

18. Ikeda H, Old LJ and Schreiber RD: The roles of IFN $\gamma$ in protection against tumour development and cancer immunoediting. Cytokine Growth Factor Rev 13: 95-109, 2002.

19. Nelson EL, Wenzel LB, Osann K, et al: Stress, immunity and cervical cancer: biobehavioural outcomes of a randomized clinical trial. Clin Cancer Res 14: 2111-2118, 2008.

20. Neuner A, Schindel M, Wildenberg U, Muley T, Lahm H and Fischer JR: Prognostic significance of cytokine modulation in non-small cell lung cancer. Int J Cancer 101: 2872-2892, 2002.

21. O'Hara RJ, Greenman J, MacDonald AW, et al: Advanced colorectal cancer is associated with impaired interleukin 12 and enhanced interleukin 10 production. Clin Cancer Res 4: 1943-1948, 1998

22. Webster Marketon JI and Glaser R: Stress hormones and immune function. Cell Immunol 252: 16-26, 2008.

23. Lightman SL: The neuroendocrinology of stress: a never ending story. J Neuroendocrinol 20: 880-884, 2008.

24. Dohi K, Kraemer WJ and Mastro AM: Exercise increases prolactin-receptor expression on human lymphocytes. J Appl Physiol 94: 518-524, 2003.

25. Gotovac K, Sabioncello A, Rabatic S, Berki T and Dekaris D: Flow cytometric determination of glucocorticoid receptor (GCR) expression in lymphocyte subpopulations: lower quantity of GCR in patients with post-traumatic stress disorder (PTSD). Clin Exp Immunol 131: 335-339, 2003.

26. Rapaport R, Sills IN, Green L, et al: Detection of human growth hormone receptors on IM-9 cells and peripheral blood mononuclear cell subsets by flow cytometry: correlation with growth hormone-binding protein levels. J Clin Endocrinol Metab 80: 2612-2619, 1995.

27. Malarkey WB and Mills PJ: Endocrinology: the active partner in PNI research. Brain Behav Immun 21: 161-168, 2007.

28. Besedovsky HO and Rey AD: Physiology of psychoneuroimmunology: a personal view. Brain Behav Immun 21: 34-44, 2007.

29. Leonard BE: The HPA and immune axes in stress: the involvement of the serotonergic system. Eur Psychiatry 20 (Suppl 3): 302-306, 2005.

30. Ross K: Mapping pathways from stress to cancer progression. J Natl Cancer Inst 100: 914-917, 2008.

31. Facchinetti F, Tarabusi $\mathrm{M}$ and Volpe A: Cognitive-behavioral treatment decreases cardiovascular and neuroendocrine reaction to stress in women waiting for assisted reproduction. Psychoneuroendocrinology 29: 162-173, 2004.

32. Gaab J, Blattler N, Menzi T, Pabst B, Stoyer S and Ehlert U: Randomized controlled evaluation of the effects of cognitivebehavioral stress management on cortisol responses to acute stress in healthy subjects. Psychoneuroendocrinology 28: 767-779, 2003.

33. McKinney CH, Antoni MH, Kumar M, Tims FC and McCabe PM: Effects of guided imagery and music (GIM) therapy on mood and cortisol in healthy adults. Health Psychol 16: 390-400, 1997.

34. Cruess DG, Antoni MH, McGregor BA, et al: Cognitivebehavioral stress management reduces serum cortisol by enhancing benefit finding among women being treated for early stage breast cancer. Psychosom Med 62: 304-308, 2000. 
35. Turner-Cobb JM, Sephton SE, Koopman C, Blake-Mortimer J and Spiegel D: Social support and salivary cortisol in women with metastatic breast cancer. Psychosom Med 62: 337-345, 2000.

36. Van der Pompe G, Duivenvoorden HJ, Antoni MH, Visser A and Heijnen CJ: Effectiveness of a short-term group psychotherapy program on endocrine and immune function in breast cancer patients: an exploratory study. J Psychosom Res 42: 453-466, 1997.

37. Heinrichs M, Baumgartner T, Kirschbaum C and Ehlert U: Social support and oxytocin interact to suppress cortisol and subjective responses to psychosocial stress. Biol Psychiatry 54: 1389-1398, 2003.

38. Eremin O, Walker MB, Simpson E, et al: Immuno-modulatory effects of relaxation training and guided imagery in women with locally advanced breast carcinoma undergoing multimodality treatment. Breast 18: 17-25, 2008.

39. Andersen BL, Farrar WB, Golden-Kreutz DM, et al: Psychological, behavioral and immune changes after a psychological intervention: a clinical trial. J Clin Oncol 22: 3570-3580, 2004.

40. McGregor BA, Antoni MH, Boyers A, Alferi SM, Blomberg BB and Carver CS: Cognitive-behavioural stress management increases benefit finding and immune function among women with early stage breast cancer. J Psychosom Res 56: 1-8, 2004.

41. Hernandez-Reif M, Ironson G, Field T, et al: Breast cancer patients have improved immune and neuroendocrine functions following massage therapy. J Psychosom Res 57: 45-52, 2004.

42. Walker LG, Walker MB, Ogston K, et al: The psychological, clinical and pathological effects of relaxation training and imagery during primary chemotherapy. Br J Cancer 80: 262-268, 1999.

43. Fawzy FI, Kemeny ME, Fawzy NW, Elashoff R, Morton D, Cousins $\mathrm{N}$ and Fahey JL: A structured psychiatric intervention for cancer patients. II. Changes over time in immunological measures. Arch Gen Psychiatry 47: 729-735, 1990.

44. Walker LG: Psychosocial Oncology in Hull and the East Riding of Yorkshire. Newsletter of the British Psychosocial Oncology Society, March: 10-12, 2000.

45. Anderson BL: Psychological interventions for cancer patients to enhance quality of life. J Consult Clin Psychol 60: 552-568, 1992.

46. Boyum A: Isolation of leucocytes from human blood. Further observations. Methylcellulose, dextran and ficoll as erythrocyteaggregating agents. Scand J Clin Lab Invest 97: 31-50, 1968.

47. Jung T, Schauer U, Heusser C, Neuman C and Rieger C: Detection of intracellular cytokines by flow cytometry. J Immunol Methods 159: 197-207, 1993.

48. Piriou L, Chilmonczyk S, Genetet N and Albina E: Design of a flow cytometric assay for the determination of natural killer and cytotoxic T-lymphocyte activity in human and in different animal species. Cytometry 41: 289-297, 2000.

49. Carlens S, Gilljam M, Chambers BJ, et al: A new method for in vitro expansion of cytotoxic human CD3-CD56+ natural killer cells. Hum Immunol 62: 1092-1098, 2001.

50. Vickers AJ and Altman DG: Statistics notes: analysing controlled trials with baseline and follow-up measurements. BMJ 323 1123-1124, 2001

51. Carlson LE, Speca M, Patel KD and Goodey E: Mindfulnessbased stress reduction in relation to quality of life, mood, symptoms of stress, and immune parameters in breast and prostate cancer outpatients. Psychosom Med 65: 571-581, 2003.
52. Wilkinson SM, Love SB, Westcombe AM, et al: Effectiveness of aromatherapy massage in the management of anxiety and depression in patients with cancer: a multicentre randomized controlled trial. J Clin Oncol 25: 532-539, 2007.

53. Kuss I, Hathaway B, Ferris RL, Gooding W and Whiteside TL: Imbalance in absolute counts of T lymphocyte subsets in patients with head and neck cancer and its relation to disease. Adv Otorhinolaryngol 62: 161-172, 2005.

54. Hong WS, Min Y, Son YS and Hong S: Peripheral blood lymphocyte subsets in patients with stomach cancer. J Korean Med Sci 10: $164-168,1995$.

55. Heys SD, Gough DB and Eremin O: Immunotherapy with interleukin-2, recent developments. Expert Opin Investig Drugs 5: 269-288, 1996.

56. Al Sarireh B and Eremin O: Tumour associated macrophage (TAMS): disordered function, immune suppression and progressive tumour growth. J R Coll Surg Edinb 45: 1-16, 2000.

57. Beyer M and Schultze JL: Regulatory T cells in cancer. Blood 108: 804-811, 2006.

58. Curiel TJ: Tregs and rethinking cancer immunotherapy. J Clin Invest 117: 1167-1174, 2007.

59. Trzonkowski P, Szmit E, Myśliwska J and Myśliwski A: $\mathrm{CD} 4{ }^{+} \mathrm{CD} 25^{+} \mathrm{T}$ regulatory cells inhibit cytotoxic acitivity of CTL and NK cells in humans - impact of immunosenescence. Clin Immunol 119: 307-316, 2006.

60. Hernandez-Reif M and Field T: Natural killer cells and lymphocytes increase in women with breast cancer following massage therapy. Int J Neurosci 115: 495-510, 2005.

61. Bakke AC, Purtzer MZ and Newton P: The effect of hypnoticguided imagery on psychological well-being and immune function in patients with prior breast cancer. J Psychosom Res 53: 1131-1137, 2002.

62. Brittenden J, Heys SD, Ross J and Eremin O: Natural killer cells and cancer. Cancer 77: 1226-1243, 1996.

63. Malmberg KJ, Bryceson YT, Carlsten M, et al: NK cell-mediated targeting of human cancer and possibilities for new means of immunotherapy. Cancer Immunol Immunother 57: 1541-1552, 2008.

64. Joshi AD, Clark EM, Wang P, et al: Immunotherapy of human neuroblastoma using umbilical cord blood-derived effector cells. J Neuroimmune Pharmacol 2: 202-212, 2007.

65. Godoy-Ramirez K, Franck K and Gaines H: A novel method for the simultaneous assessment of natural killer cell conjugate formation and cytotoxicity at the single-cell level by multiparameter flow cytometry. J Immunol Methods 239: 35-44, 2000.

66. Glaser R, Maccallum RC, Laskowski BF, Malarkey WB, Sheridan JF and Kiecolt-Glaser JK: Evidence for a shift in the Th-1 to Th- 2 cytokine response associated with chronic stress and ageing. J Gerontol A Biol Sci Med Sci 56: 477-482, 2001.

67. Carlson LE, Speca M, Patel KD and Goodey E: Mindfulnessbased stress reduction in relation to quality of life, mood, symptoms of stress and levels of cortisol, dehydroepiandrosterone sulfate (DHEAS) and melatonin in breast and prostate cancer outpatients. Psychoneuroendocrinology 29: 448-474, 2004.

68. Walker AA, Walker MB, Greenman J, Sharp DM and Walker LG: Does reflexology improve quality of life in women who have undergone surgery for early breast carcinoma? Psychooncology 15: S137, 2006. 